\title{
ORIGINAL ARTICLE Comparison of chromosomal aberrations frequency and polymorphism of GSTs genes in workers occupationally exposed to cytostatics or anaesthetics
}

\author{
L’udovít MUŠÁK 1,2, Erika HALAŠOVÁ 1, Tatiana MATÁKOVÁ 3, Lucia LETKOVÁ 3, Ludmila VODIČKOVÁ 4,5, \\ Janka BUCHANCOVÁ 6 , Henrieta HUDEČKOVÁ 6 , Oto OSINA ${ }^{2}$, Pavel SOUČEK ${ }^{4}$, Pavel VODIČKA 5 \\ 1 Institute of Medical Biology, Comenius University in Bratislava, Jessenius Faculty of Medicine in Martin, Slovakia \\ ${ }^{2}$ Clinic of Occupational Medicine and Toxicology, Comenius University in Bratislava, Jessenius Faculty of Medicine in Martin, Slovakia \\ 3 Institute of Medical Biochemistry, Comenius University in Bratislava, Jessenius Faculty of Medicine in Martin, Slovakia \\ ${ }^{4}$ National Institute of Public Health in Prague, Czech Republic \\ 5 Institute of Experimental Medicine Academy of Sciences in Prague, Czech Republic \\ 6 Institute of Public Health, Comenius University in Bratislava, Jessenius Faculty of Medicine, Slovakia
}

ITX020309A03 • Received:04 August 2009 • Revised:25 August 2009 • Accepted: 27 August 2009

\begin{abstract}
Authors compared the incidence of chromosomal aberrations (CAs) of workers occupationally exposed to cytostatics (group EXP1) or anaesthetics (group EXP2) in relationship to polymorphism of GSTM1, GSTP1 and GSTT1 genes. The cytogenetic analysis for chromosomal aberrations frequency and for polymorphisms of genes the PCR and PCR-RFLP method were used. Statistically higher frequency of total CAs was detected in both exposed groups: group EXP1 1.90 $\pm 1.34 \%$; Mann-Whitney U-test, $p=0.001$; group EXP2 2.53 $\pm 1.46 \%$, $p=0.0008)$ as compared to control (1.26 $\pm 0.93 \%)$. In group EXP2 was detected statistically higher frequency of aberrations CSA-type as compared to CTA-type. In xenobiotic metabolizing genes for GST higher frequency of total CAs and constituent types chromatid-type aberrations (CTAs) and chromosome-type aberrations (CSAs) of genes GSTM1 and GSTT1 with null genotype was detected. Statistically significant difference was detected only in CSA-type of aberrations in GSTT1 gene. In gene GSTP1 was not detected any difference in frequency of aberrations in presence of the variant allele. Presented results point out importance of individual susceptibility in evaluation of genotoxic agents of anaesthetics or cytostatics.
\end{abstract}

KEY WORDS: chromosomal aberrations; cytostatics; anaesthetics; occupational exposure; polymorphisms of GST genes

\section{Introduction}

The mutagenic, carcinogenic and cytotoxic effect of cytostatics (IARC 1996, Burgaz et al., 2002, Cavallo et al., 2005; Cavallo et al., 2007; Rekhadevi et al., 2007; Poljaková et al., 2008) and anaesthetics (IARC 1996, Jaloczynski 1999, Karpinski 2005) is permanently discussed. Workers in oncological units are occupationally excessively exposed to low doses of cytostatics and anaesthesiologists to volatile anaesthetics in the long term. Cytostatics genotoxicity is expressed especially by undirected damage of genetic

Correspondence address:

RNDr. L’udovít Mušák, PhD.

Institute of Medical Biology, Jessenius Faculty of Medicine Comenius University, Mala Hora Str. N. 4, 03754 Martin, Slovakia

PHONE: +421-43-4131 425

E-MAll: musak@ifmed.uniba.sk material. The most of mutagens are electrophilic agents, or can be metabolised by electrophilic intermediators. Connor (2006) reports that the skin is the first meeting point of antineoplastic agents' contamination. After occupational exposure to cytostatics the increased frequency of chromosomal aberrations, sister chromatid exchanges (SCE) or micronuclei $(\mathrm{MN})$ in cells was described by many authors (Pilger et al., 2000; Burgaz et al., 2002). Musak et al. (2006) published the higher frequency of CAs in variant type of alleles in DNA repair genes XRCC1 exon 10 and XRCC3 exon 7 and Mušák et al. (2008) detected statistically decrease of total CAs and CTAs in presence of variant allele. Testa et al. (2007) did not find out significant relationship between polymorphisms of genes for GST and higher frequency of CAs. Angelini et al., (2008) detected important influence of genotype GSTT(-), in healthy individuals and after exposure to bleomycine (BLM). Rombaldi et al. (2009) analysed the genotoxicity using comet assay, and $\mathrm{MN}$ test as well as the level of oxidative stress. The exposed workers 
presented increased DNA damage levels by the comet assay as compared to the controls. The comet assay results have also shown significant positive correlation with the length of exposure and with the amount of consumed alcohol.

The anaesthesiologists are excessively occupationally exposed to volatile anaesthetics. The genotoxicity of desflurane was assessed by comet assay as extent of DNA fragmentation in peripheral human lymphocytes in vitro. The increased DNA migration was detected not only in cells exposed to halothane, but also to desflurane (Karpinski et al., 2005). There was not detected any increase of chromosomal aberrations' number in patients exposed to anaesthetics during operation evidencing (Karahalil et al., 2005). Exposure to residues anaesthetics can increase the genetic damage comparable with damage caused by smoking $11-20$ cigarettes per day (Hoerauf et al., 1999). The increased incidence of CAs was detected by Rozgaj et al. (1999) in medical workers in operating rooms. Rozgaj and Kasuba (2000) and Rozgaj et al. (2001) assessed frequencies of CA, MN and SCE in anaesthesiologists, and found their increase particularly in females. Bilban et al. (2005) found out increased frequency of CAs (2.69\%) in medical workers of operating and reaniming rooms, which was comparable to group of radiologists. The increase of DNA damage was detected as well by Chandrasekhar et al. (2006) using comet assay, MN test and peripheral blood lymphocytes analysis in buccal mucosa cells. His findings were not dependent on age and gender of observed persons.

The aim of study is detection of genotoxic effect's biomarkers - total CAs, chromatid-type (CTAs) and chromosome-type (CSAs) of chromosomal aberrations, and evaluation of individual susceptibility of GSTM1, GSTP1 and GSTT1 genes in medical workers occupationally exposed to cytostatics or anaesthetics.

\section{Material and methods}

Seventy two workers (group EXP1) occupationally exposed to cytostatics and 76 workers (group EXP2) exposed to anaesthetics were analysed for frequency of chromosomal aberrations and polymorphisms of GST genes in comparison to control individuals. All of them completed anamnestic questionnaire about length and way of exposure, job categorize, exogenous factors (smoke, drug usage, exposure to radiation, alcohol consumption and dietary) before blood collection and give an approving to be involved in the study. Group EXP1 represented workers from specialized oncologic departments from three hospitals in north part middle Slovakia region - Faculty Hospital in Martin ( $\mathrm{n}=28)$, Central Military Hospital in Ružomberok $(n=31)$ and Hospital with Polyclinic in Trstená $(n=13)$. All of workers were regularly in contact with cytostatics that dilute and apply to patients. By job grade they are classified as nurses (80.55\%) and physicians. Both groups consist predominantly of females (90.28\%). Smokers presented 26.39\%. Group EXP2 consists of 76 workers from Faculty Hospital in Martin ( $\mathrm{n}=60)$ and Central Military Hospital in Ružomberok $(n=16)$. All of workers were regularly exposed to volatile anaesthetics. By job grade they are classified as anaesthesiologic physicians (53.95\%) and nurses (46.05\%). They participated in application of volatile anaesthetics during surgical interventions in complete anaesthesia in operating rooms. Groups consist predominantly of female persons (80.26\%). Smokers presented 30.26\%. Control group consisted of workers of Medical Faculty Hospital in Martin and workers from Biotika factory in Martin. They were not exposed to any genotoxic agents. Characteristics of both exposed groups and control are present in Table 1. We microscopically analysed 100 mitoses per person and evaluated the frequency of total chromosomal CAs, and constituent types: CTA-type and CSA-type of aberrations. Methodology of cytogenetic analysis was performed according to AHEM (2007). Polymorphisms of GST genes were performed by PCR methods. Gene GSTM1 primers - F (forward): 5'-CTG CCC TAC TTG ATT GAT G-3'; R (reverse): 5'-CTG GAT TGT AGC AGA TCA TGC-3'; size of fragments: 1) normal homozygote or heterozygote (GSTM1-plus) - 275bp (GSTM1) and 175 bp (GSTM2), 2) variant homozygote (GSTM-null) - GSTM1 product not form and $175 \mathrm{bp}$ (GSTM2). Genes GSTP1 and GSTT1 primers GSTP1-F (forward): 5' - TCC TTC CAC GCA CAT CCT CT-3'; GSTP1-R (reverse): 5'-AGC CCC TTT CTT TGT TCA GC-3'; GSTT1-F (forward): 5'-TTC CTT ACT GGT CCT CAC ATC TC-3'; GSTT1-R (reverse): TCA CCG GAT CAT GGC CAG CA; size of fragments 1) normal homozygote or heterozygote (GSTT1-plus) - $480 \mathrm{bp}$; 2) variant homozygote (GSTM-null) - product not form; restriction enzyme BsmAI, size of fragments: 1) normal homozygote (Ile105Ile) - 294 bp, 2) heterozygote (Ile105Val) - 294+234+60 bp, 3) variant homozygote (Val105Val) $-234+60 \mathrm{bp}$. All principles for protection personnel data, for health care are accepted in this paper. Peripheral blood sampling was realized within the specialised medical examinations. Statistical analysis was performed by program Statgraphics, version 7 (Manugistics, Cambridge, MA). There was used nonparametric MannWhitney U-test for testing differences between groups and analysis of variance (ANOVA) for testing relationships between biomarkers and genotype. The values in tables are as average \pm standard deviation (S.D.)

\section{Results}

We detected statistically higher frequency of total chromosomal aberrations (CAs) in group EXP1 (1.90 $\pm 1.34 \%$; $p=0.001)$ and group EXP2 $(2.53 \pm 1.46 \% ; p=0.0008)$ in comparison to control $(1.26 \pm 0.93 \%)$. In group EXP1 we did not detect any difference between CTA-type and CSA-type $-0.92 \pm 1.04 \%$ vs. $0.98 \pm 1.17 \%$; on the contrary in group EXP2 we detected statistically higher frequency of aberrations CSA-type in comparison to CTA-type $(1.92 \pm 1.38 \%$ vs. $0.61 \pm 0.83 \%$; $p=0.0009)$. Evaluating the role of polymorphisms of GSTM1 gene we did not observed significant difference in group EXP1, but in group EXP2 we detected the increase of total CAs, CTA-type and CSAtype in null variant as compared to plus variant (Figures 1, 2 and 3). Evaluating of GSTP1 gene polymorphisms we 


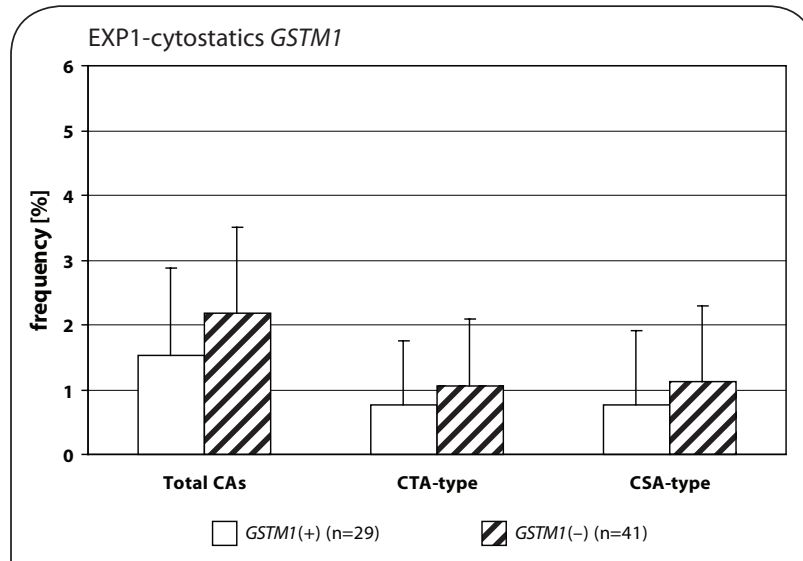

Figure 1. Polymorphisms of GSTM1 gene in exposed group to cytostatics.

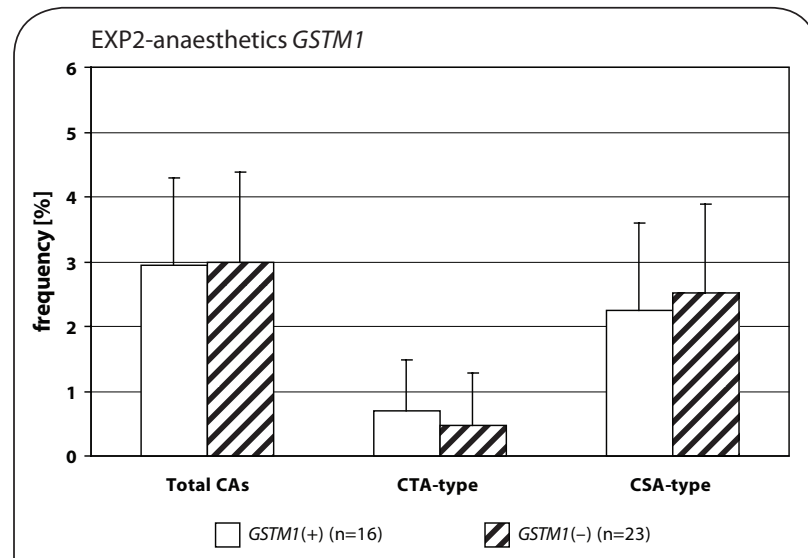

Figure 2. Polymorphisms of GSTM1 gene in exposed group to anaesthetics.

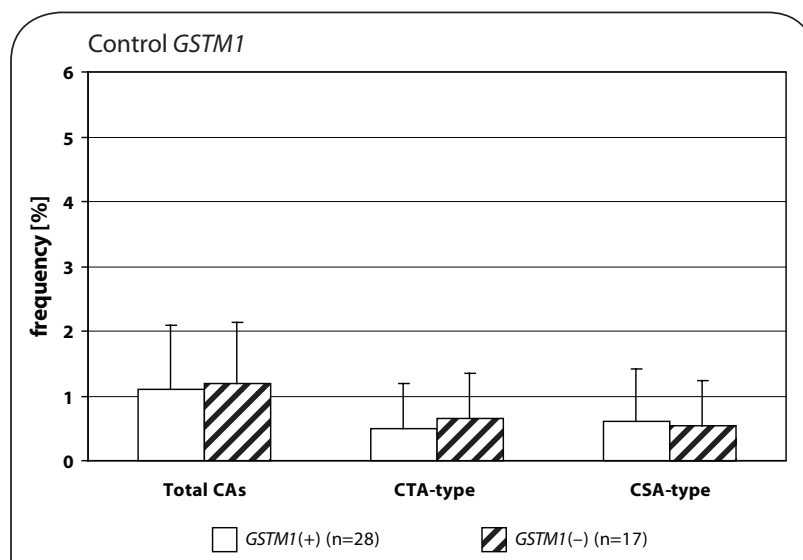

Figure 3. Polymorphisms of GSTM1 gene in control group.

did not detect any differences in presence of variant allele (Figures 4, 5 and 6). Evaluation of GSTT1 gene showed slightly increase of total CAs, and CTA-type in group EXP1, and higher (statistically not significant) frequency of total CAs as well as significant difference $(p=0.05)$ in null variant as compared to plus variant of CSA-type in group EXP2 (Figures 7, 8 and 9).
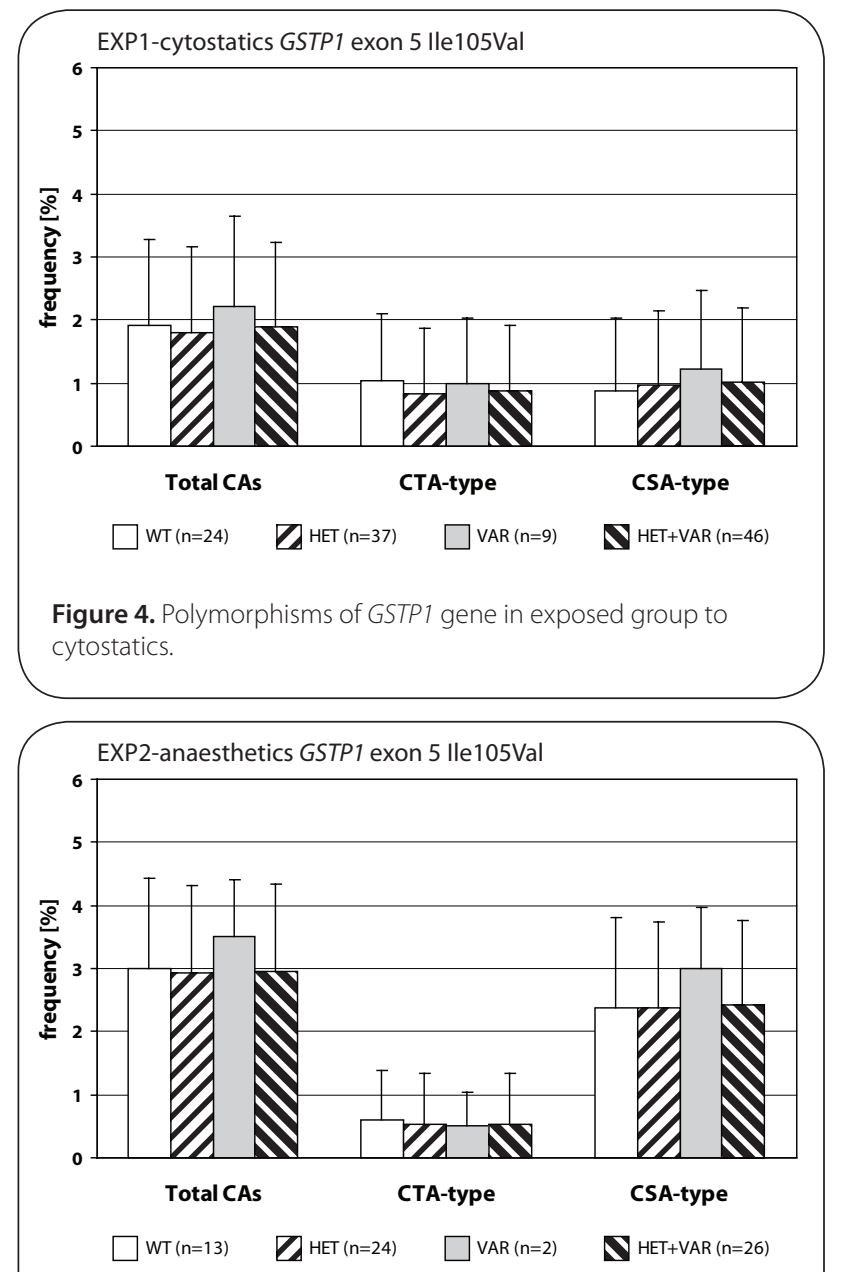

Figure 5. Polymorphisms of GSTP1 gene in exposed group to anaesthetics.

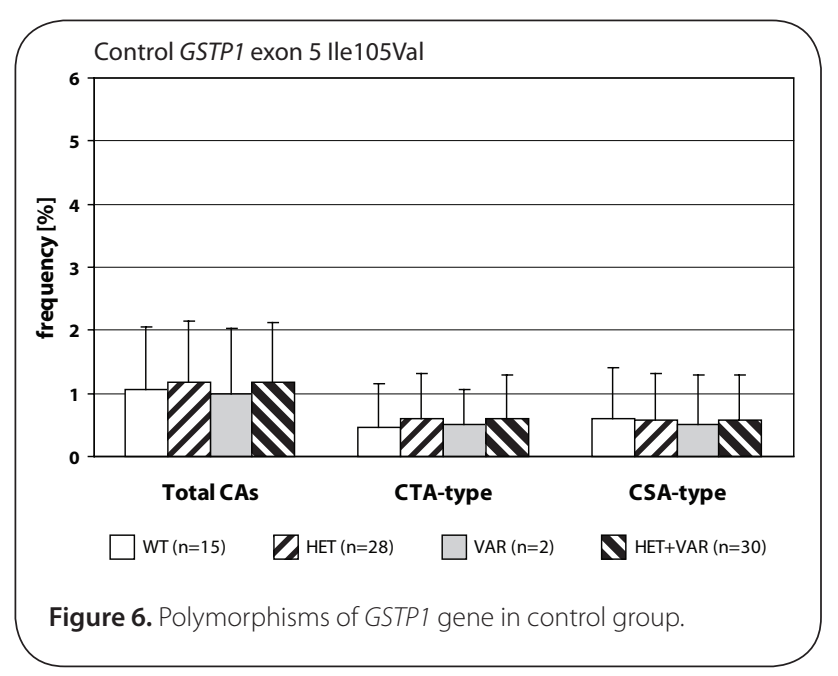

\section{Discussion}

Cytostatics are mutagenic and carcinogenic agents (Vorlíček et al., 2000). They cause variously DNA damage. Burgaz et al. (2002) and Cavallo et al. (2005) examined workers in contact with cytostatics (nurses and pharmaceutical workers that prepared, diluted or applied cytostatics; orderlies in 

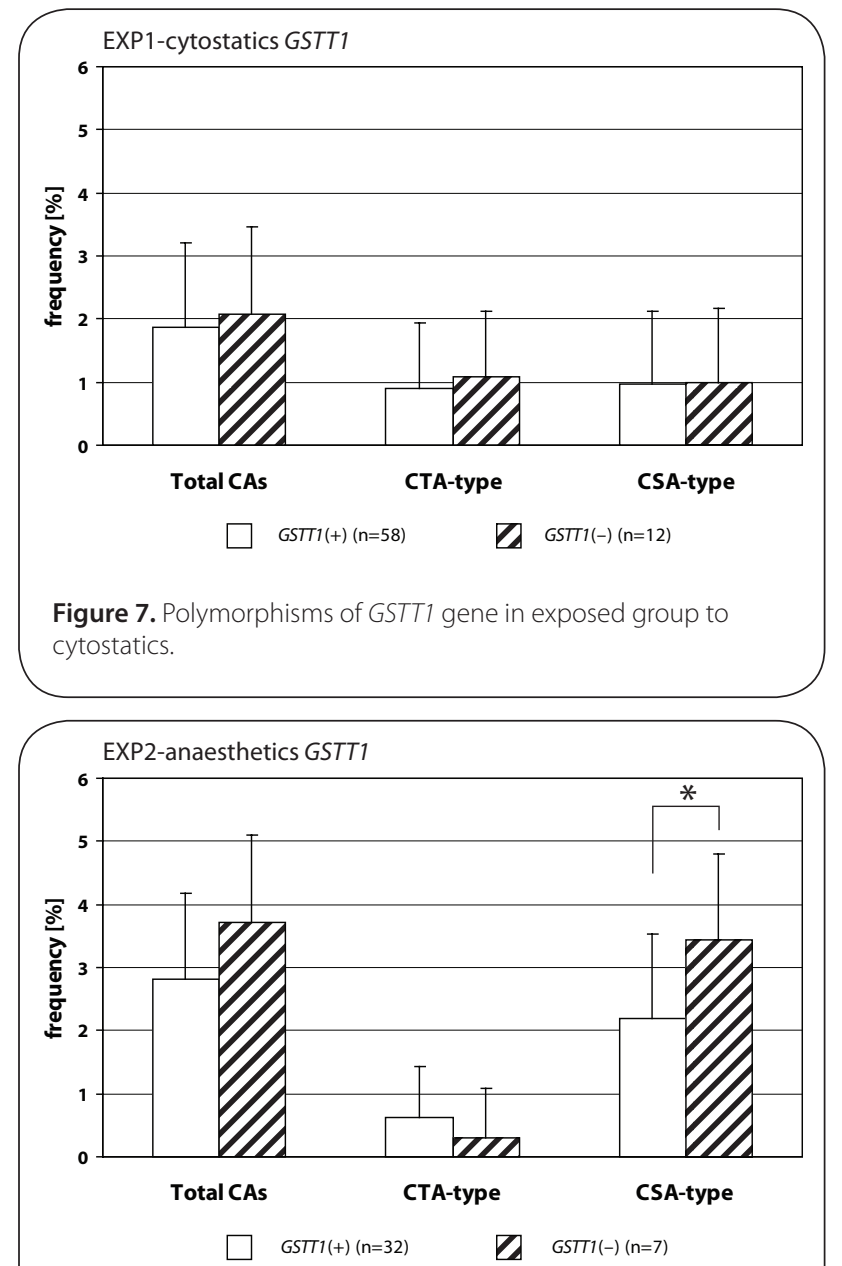

Figure 8. Polymorphisms of GSTT1 gene in exposed group to anaesthetics.

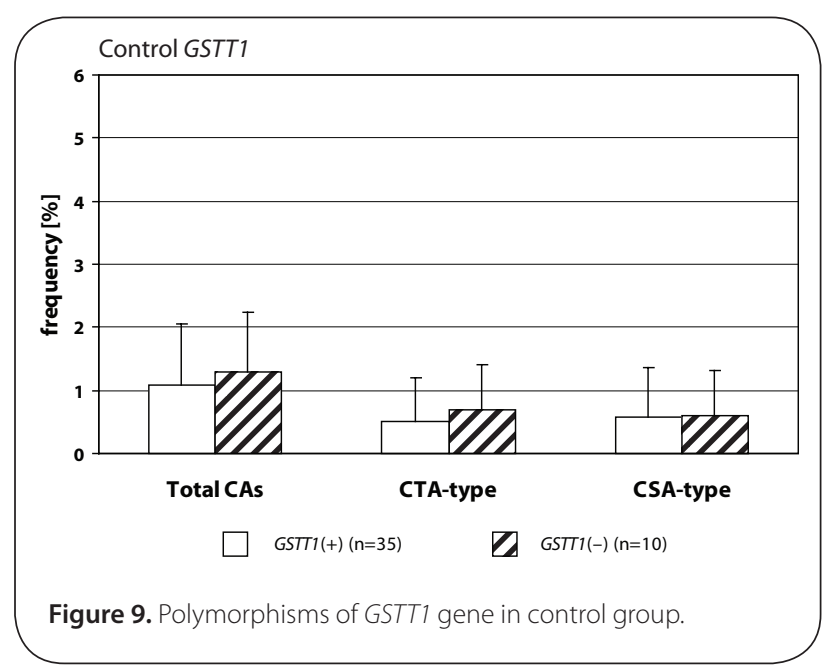

contact with bed sheets and possibly excrements of treated patients). They both observed the higher frequency of CAs and $\mathrm{MN}$ in buccal mucosa cells in exposed workers. Burgaz et al. (2002) detected 2.5-time higher frequency of CAs in exposed persons.

Anaesthesiology workers are notable exposed to volatile anaesthetics during occupational activity. In many papers is

\begin{tabular}{|c|c|c|c|}
\hline & EXP1 & EXP2 & Control \\
\hline Number & 72 & 76 & 76 \\
\hline Age (years $\pm S . D)$. & $41.19 \pm 8.95$ & $36.89 \pm 8.75$ & $35.99 \pm 7.73$ \\
\hline Exposure (years \pm S.D.) & $11.31 \pm 8.98$ & $11.75 \pm 9.35$ & \\
\hline $\operatorname{Sex}(N) M / F$ & $7 / 65$ & $15 / 61$ & $16 / 60$ \\
\hline Smoking (N) S/NS & $19 / 53$ & $23 / 53$ & $15 / 61$ \\
\hline Job (N) physician/nurse & $14 / 58$ & $41 / 35$ & $20 / 56$ \\
\hline
\end{tabular}

Table 2. Chromosomal aberrations expressed percentage in exposed groups and control.

\begin{tabular}{lccc|}
\hline & $\begin{array}{c}\text { Number of } \\
\text { mitosis (N) }\end{array}$ & $\begin{array}{c}\text { Number of } \\
\text { Ab.c. (N) }\end{array}$ & $\begin{array}{c}\text { Percentage of } \\
\text { CAs (\%) } \pm \text { S.D. }\end{array}$ \\
\hline EXP1 - cytostatics & 7200 & 137 & $1.90 \pm 1.34^{* * *}$ \\
\hline EXP2 - anaesthetics & 7600 & 192 & $2.53 \pm 1.46^{* * *}$ \\
\hline Control & 7600 & 96 & $1.26 \pm 0.93$ \\
\hline
\end{tabular}

${ }^{* * *} p=0.001(\operatorname{EXP} 1) ;{ }^{* * *} p=0.0008(\operatorname{EXP} 2)-$ total CAs exposed vs. control

presented the increase of aberrant cells in operating rooms workers (Rozgaj et al., 1999; Rozgaj et al., 2001; Natarajan, 2002). Our findings are in accordance with previously mentioned; we detected statistically higher frequency of total CAs in group EXP1 and group EXP2 as well. Numerous authors determined in their explorations that the increased risk to exposure of genotoxic agents is related with inconsistent observance of safety regulations. The higher exposures to cytostatics were observed at workplaces, where the personnel was not adequately informed about risk associated with this job (Connor, 2006; Fransman et al., 2007a; Fransman et al., 2007b ). The increased number of chromosomal aberrations in group EXP2 can be caused by unsuitable conditions of employment (i.e. not effective or inadequately effective air circulation, operating rooms without air-conditioning) in comparison to control. The extensive research of employment conditions showed, that in operating rooms with 10-12 multiple air circulation only, can be the concentration of halothane decreased to $50-80 \mathrm{mg} \cdot \mathrm{m}^{-3}$ (Wiesner et al., 2001). The role of gene-environmental interactions has been frequently discussed for last years and the research results have pointed on their relation to diseases formation in some individuals. It is believed that this interaction can be influenced by gene polymorphism (Horváthová, 2008). For the determination of CAs frequency in human lymphocytes we analysed specific polymorphisms of genes participated in metabolism of genotoxic agents. We analysed the polymorphism of GSTs genes. In gene GSTM1 and GSTT1 we detected higher frequency of total CAs and constituent types i.e. CTA-type and CSA-type in both exposed groups. 
Scarpato et al., (1997) detected the higher frequency of CAs in smokers in absence of allele GSTM1 gene (GSTM1 null variant). The absence of gene for GSTM1 and GSTT1 point out the higher frequency of CAs in comparison with presence GSTM1 gene and absence GSTT1 gene in drivers of busse (Norppa et al., 2006).

Presented results finger on importance of individual susceptibility in assessment of genotoxic effects, in cases, the concentration of genotoxic agents usually doesn't exceed the occupational exposure limits.

\section{Acknowledgments}

This work was supported by grant MZ SR 2007/48-UK-13 (SR) and IGA MZ CR 8563-5/2005 (CR).

\section{REFERENCES}

AHEM. (2007). Metody biologického monitorování genotoxických účinků faktorů prostředí. Cytogenetická analýza periferních lymfocytů. Aktualizace platné standardní metodiky. AHEM. [in Czech] 1/2007, SZÚ, Praha, 30pp

Angelini S, Kumar R, Carbone F, Bermejo JL, Maffei F, Cantelli-Forti G, Hemminki Kand Hrelia P. (2008). Inherited susceptibility to bleomycin-induced micronuclei: correlating polymorphisms in GSTT1, GSTM1 and DNA repair genes with mutagen sensitivity. Mutat Res 638: 90-97.

Bilban M, Jakopin CB and Ogrinc D. (2005). Cytogenetic tests performed on operating room personnel (the use of anaesthetic gases). Int Arch Occup Environ Health 78: 60-64.

Burgaz S, Karahalil B, Canhi Z, Terzioglu F, Ancel G, Anzion RB, Bos RP and Hüttner E. (2002). Assessment of genotoxic damage in nurses occupationally exposed to antineoplastics by the analysis of chromosomal aberrations. Hum Exp Toxicol 21: 129-135

Cavallo D, Ursini LC, Perniconi B, Di Francesco A, Giglio M, Rubino FM., Marinaccio A and lavicoli S. (2005). Evaluation of genotoxic effects induced exposure to antineoplastic drugs in lymphocytes and exfoliated buccal cells of oncology nurses and pharmacy employees. Mutat Res 587: 45-51.

Cavallo D, Ursini CL, Omodeo-Sale E and lavicoli S. (2007). Micronucleus induction and FISH analysis in buccal cells and lymphocytes of nurses administering antineoplastic drugs. Mutat Res 628: 11-18.

Connor TH. (2006). Hazardous anticancer drugs in health care:environmental exposure assessment. Ann N Acad Sci 1076: 615-623.

Fransman W, Huizer D, Tuerk J and Kromhout H. (2007a). Inhalation and dermal exposure to eight antineoplastic drugs in an industrial laundry facility. Int Arch Occup Environ Health 80: 396-403.

Fransman W, Roeleveld N, Peelen S, de Kort W, Kromhout H and Heederik D. (2007b). Nurses with dermal exposure to antineoplastic drugs: reproductive outcomes. Epidemiology 18: 112-119.

Hoerauf KH, Wiesner G, Schroegendorfer KF, Jobst BP and Spacek A. (1999). Waste anaesthetic gases induce sister chromatid exchanges in lymphocytes of operating room personnel. British J Anaesth 82: 764-766.

Horváthová E. (2008). Trends in the study of genetic susceptibility. Interdisc Toxicol 1: 13-14.

Chandrasekhar M, Rekhadevi PV, Sailaja N, Rahman MF, Reddy JP, Mahboob M and Grover P. (2006). Evaluation of genetic damage in operating room personnel exposed to anaesthetic. Mutagenesis 21: 249-254.
IARC. (1996). Monographs on the evaluation of carcinogenetic risks to humans. Some pharmaceutical drugs. Lyon, International Agency for Research on Cancer 66: 87pp.

Jaloszynski P, Kujawski M, Wasowicz M, Szulc R and Szyfter K. (1999). Genotoxicity of inhalation anesthetics halothane and isoflurane in human lymphocytes studied in vitro using the comet assay. Mutat Res 439: 199-206.

Karahalil B, Yagar S, Bahadir G, Durak P and Sardas S. (2005). Diazepam and propofol used as anesthetics during open-heart surgery do not cause chromosomal aberrations in peripheral blood lymphocytes. Mutat Res 581: 181-186.

Karpinski TM, Kostrzewska-Poczekaj M, Stachecki I, Mikstacki A and Szyfter K. (2005). Genotoxicity of the volatile anaesthetic desflurane in human lymphocytes in vitro, established by comet assay. J App/ Genet 46: 319-324.

Mušák L’, Poláková V, Halašová, E, Osina, O, Vodičková L, Buchancová, J, Hudečková H and Vodička P. (2008). Effect of occupational exposure to cytostatics and nucleotide excision repair polymorphisms on chromosomal aberrations frequency. Interdisc Toxico/ 2: 13-17.

Musak L, Vodicka P, Klimentová G, Soucek P, Hánová M, Mikulková R, Buchancová J, Vodicková L, Poláková V and Péc M. (2006). Chromosomal damage and polymorphisms of DNA repair genes XRCC1 and XRCC3 in workers exposed to cytostatics. Neuro Endocrinol Lett 27 Suppl 2: 57-60.

Natarajan AT. (2002). Chromosome aberrations:past, present and future. Mutat Res 504: 3-16.

Norppa H, Bonassi S, Hansteen IL, Hagmar L, Strömberg U, Rössner P, Boffetta P, Lindholm C, Gundy S, Lazutka J, Cebulska-Wasilewska A, Fabianova E, Sram RJ, Knudsen LE, Barale R and Fucic A. (2006). Chromosomal aberrations and SCEs as biomarkers of cancer risk. Mutat. Res 600: 37-45

Pilger A, Köhler I, Stettner H, Mader RM, Rizovski B, Terkola R, Diem E, FranzHainzl E, Konnaris CM Valic E and Rüdinger HW. (2000). Long-term monitoring of sister chromatid exchanges and micronucleus frequencies in pharmacy personnel occupationally exposed to cytostatic drugs. Int Arch Occup Environ Health 73: 442-448.

Poljaková J, Eckschlager T, Hřebačková J, Hraběta J, Stiborová M. (2008). The comparison of cytotoxicity of the anticancer drugs doxorubicin and ellipticine to human neuroblastoma cells Interdisc Toxicol 1: 186-189.

Rekhadevi PV, Sailaja N, Chandrasekhar M, Mahboob M, Rahman MF and Grove P. (2007). Genotoxicity assessment in oncology nurses handling anti-neoplastic drugs. Mutagenesis 22: 395-401.

Rombaldi F, Cassini C, Salvator M, Saffi J and Erdtmann B. (2009). Occupational risk assessment of genotoxicity and oxidative stress in workers handling antineoplastic drugs during a working week. Mutagenesis 24: 143-148.

Rozgaj R, Kasuba V and Peric M. (1999). Chromosome aberrations in operating room personnel. Am J Ind Med 35: 642-646.

Rozgaj R and Kasuba V. (2000). Chromosome aberrations and micronucleus frequency in anaesthesiology personnel. Arh Hig Rada Toksikol 51: 361-368.

Rozgaj R, Kasuba V and Jazbec A. (2001). Preliminary study of cytogenetic damage in personnel exposed to anesthetic gases. Mutagenesis 16: 139-143.

Scarpato R, Hirvonen A, Migliore L, Falck G and Norppa H. (1997). Influence of GSTM1 and GSTT1 polymorphisms on the frequency of chromosome aberrations in lymphocytes of smokers and pesticide-exposed greenhouse workers. Mutat. Res 389: 1997, 227-235.

Testa A, Giachelia M, Palma S, Appolloni M, Padua L, Tranfo G, Spagnoli M, Tirindelli D and Cozzi R. (2007). Occupational exposure to antineoplastic agents induces a high level of chromosome damage. Lack of an effect of GST polymorphisms. Toxicol Appl Pharmacol 223: 46-55

Vorlíček J, Vyzula R and Adam Z. (2000). Praktická onkologie, vybrané kapitoly. Grada Publishing s.r.o. [in Czech] Praha, pp.77-154.

Wiesner G, Hoerauf K, Schroegendorfer K, Sobczynski P, Harth M and Ruediger HW. (2001). High-level, but not low-level, occupational exposure to inhaled anesthetics is associated with genotoxicity in the micronucleus assay. Anesth Analg 92: 118-122 